Szpytma Dorota, Nowak Patrycja, Obuchowska Anna, Rząca Marcin, Wegorowski Pawel. Acceptance of suffering and death due to cancer in the religions of the world. Journal of Education, Health and Sport. 2019;9(12):75-81. eISSN 2391-8306. DOI http://dx.doi.org/10.12775/JEHS.2019.09.12.008

https://apcz.umk.pl/czasopisma/index.php/JEHS/article/view/JEHS.2019.09.12.008

https://zenodo.org/record/3581259

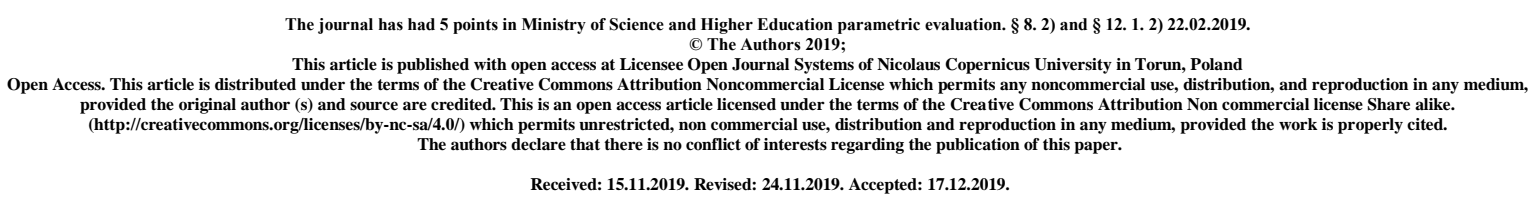

\title{
Acceptance of suffering and death due to cancer in the religions of the
} world

\author{
Dorota Szpytma ${ }^{1}$, Patrycja Nowak ${ }^{1}$, Anna Obuchowska ${ }^{1}$, Marcin Rząca ${ }^{2}$, Pawel \\ Węgorowski ${ }^{2}$
}

${ }^{1}$ Students scientific association, Chair of Oncology and Environmental Health, Medical

University of Lublin, Poland (Studenckie Koło Naukowe, Katedra Onkologii i Środowiskowej Opieki Zdrowotnej, Uniwersytet Medyczny w Lublinie, Polska)

${ }^{2}$ Department of Oncology, Chair of Oncology and Environmental Health, Medical

University of Lublin, Poland (Zakład Onkologii, Katedra Onkologii i Środowiskowej Opieki Zdrowotnej, Uniwersytet Medyczny w Lublinie, Polska)

\section{Summary:}

Cancer undoubtedly occurs in human life as unwanted. Finding yourself in a situation of cancer, it generates a series of thoughts, events that result in the need to confront the new reality. The sense of threat to life makes a person changes the mode of operation and a hierarchy of important things for him. Polish proverb "when in fear, God is near" aptly interprets human behavior in a difficult situation. Often, in such a situation a person is looking for support in religion, religion often begins to have a new meaning for the patient, while being the source of the sense of safety. Thanks to it, religion can shape the patient's level of hope. As the result the patient can better cope with the difficulties to give peace and balance of spirit, certainly needed to overcome the disease and persist in it.

The aim of the study was the location of the phenomenon of death and suffering of cancer in the context of cancer.

\section{Conclusions:}

1.Majority of religions of the world see suffering as an important part of the way of life, which can provide a relief for those suffering from cancer.

2.Most of the major religions of the world present the vision of the immortal soul, which gives hope to the dying people, that life does not end, but it will last, but in a different form.

3.Atheism, as well as low levels of religiosity may increase the fear of death and impede acceptance of suffering. 
4. Developing knowledge by medical staff about the religion should be their good practice, allowing them to better understand and support patients.

Key words: aspect of death; religiosity; acceptance of suffering

\section{Introduction:}

A condition threatening our lives or health, limits our possibilities of self-development and professional activity, but it does not limit the possibilities of development in the spiritual perspective. This work attempts to analyze the function of religion, both positive and negative conditioning in the sense of the mental quality of life of patients.

Today, cancer is one of the biggest problems of the modern world. In developed countries such as the United Kingdom, cancer is the first cause of death [1]. Similar study was also carried in Poland. In Greater Poland, one of the most industrialized regions of Poland, there is increasing tendency of the morbidity and mortality caused by tumors [2]. Higher diagnostic efficiency and aging of the population will cause continue this tend to increase. Unfortunately, despite the development of medicine cancer is the second cause of death in Poland [3]. Also, epidemiological predictions leave no doubt, that cancer will be one of the leading causes of death in Poland. In spite of the decreasing trend in mortality due to cancer in rich countries, ie. European Union states, the countries with medium and low income are been registering an increase in the absolute, or only relative increase in cancer mortality at best [4].

It is estimated that in 2018. Worldwide was 18 millions of new cases of cancer, of which 9.5 million cases involved men and 8.5 million women. [5]

According to the WCRF (World Cancer Research Fund) in 2018, top five places according to the frequency of cancer occurrence without gender differentiation were: lung cancer $(12.3 \%)$, breast cancer $(12,3 \%)$, colorectal cancer $(10.6 \%)$, prostate cancer $(7.5 \%)$ and gastric cancer (6.1\%) (Tab. 1).

Tab. 1 Frequency of cancer occurrence without gender differentiation by WCRF in the world (2018)

\begin{tabular}{|l|l|}
\hline Type of cancer & Both sexes \\
\hline Lung cancer & $12.3 \%$ \\
\hline Breast cancer & $12.3 \%$ \\
\hline Colon cancer & $10.6 \%$ \\
\hline Prostate cancer & $7.5 \%$ \\
\hline Stomach cancer & $6.1 \%$
\end{tabular}

Source: WCRF https: //www.wcrf.org/dietandcancer/cancer-trends/worldwide-cancer-data?, 28.11.2019

There is a significant gender gap due to the incidence profile of the most common malignancies in the world. Among men in the first five are lung cancer (15.5\%), prostate cancer $(14.5 \%)$, colorectal cancer $(11.4 \%)$, gastric cancer $(7.8 \%)$ and liver cancer $(6.8 \%)$. (Tab. 2). Among women in the first five places are breast cancer $(25.4 \%)$, followed by colorectal cancer $(9.7 \%)$, lung cancer $(8.8 \%)$, cervical cancer $(6.9 \%)$ and thyroid cancer $(6$, 3\%) (Table 3) [6]

Tab. 2 The occurrence of the most common cancers in men by WCRF in 2018 in the world

\begin{tabular}{|l|l|}
\hline Type of cancer & Men \\
\hline Lung cancer & $15.5 \%$ \\
\hline Prostate cancer & $14.5 \%$ \\
\hline Colon cancer & $11.4 \%$ \\
\hline Stomach cancer & $7.8 \%$ \\
\hline
\end{tabular}


\begin{tabular}{|l|l}
\hline Liver cancer & $6.8 \%$
\end{tabular}

Source: WCRF https: //www.wcrf.org/dietandcancer/cancer-trends/worldwide-cancer-data? 28.11.2019

Tab. 3 Occurrence of the most common malignancies in women by WCRF in 2018 in the world

\begin{tabular}{|l|l|}
\hline Type of cancer & Women \\
\hline Breast cancer & $25.4 \%$ \\
\hline Colon cancer & $9.7 \%$ \\
\hline Lung cancer & $8.8 \%$ \\
\hline Cervical cancer & $6.9 \%$ \\
\hline Thyroid cancer & $6.3 \%$
\end{tabular}

Source: WCRF https: //Www.wcrf.org/dietandcancer/cancer-trends/worldwide-cancer-data? 28.11.2019

\section{Cancer treatment}

Cancer is characterized by a high mortality. It is often perceived by the patients and their families as a death penalty. They are less often aware that cancer is often curable when detected early.

Various methods are used for cancer treatment. When they are used in combination can also cause a lot of side effects that many patients recognize as highly burdensome. Undesirable effects resulting from chemotherapy include all rapidly dividing cells of the body. Side effects consist of hair loss (which is particularly troublesome for women), problems with the gastrointestinal mucous membrane irritation, a significant drop in effectiveness of immune system. Harmless infection may contribute to the patient's death. [7]

Information on the occurrence of cancer is often associated with great shock and lack of acceptance of the situation. That's why extremely important is holistic, which in addition to a visible image of the patient's clinical also draws attention to his situation in life based on the uniqueness of every life. It takes into consideration the whole functioning of our being as a body, soul, mind and emotions. Thus it draws attention to the human dignity of the patient and not just looking at him through the prism of the disease. It focuses not only for combat the symptoms but also treating the causes that may have different sources.

$t$ also gives the opportunity to involve the family, loved ones and at the same time it gives the patient the opportunity to accept the situation and allows him to take control of his condition. [8].

Holistic model of care consists of physical, psychological, social and spiritual parts. Physical part focuses on performing appropriate medical actions to cause visible, positive changes in the patient's body. Mental part focuses on the behavior of the patient, and exactly on his psyche. Appropriate coping with the disease, changes the approach to the disease and healing processes, which improves the general condition. The approach of society and the support of others also plays an important point. The role of the spiritual sphere is often ignored and neglected because of the ambiguity of evaluating the effectiveness of these remedies. However, the main problem is based on a lack of full understanding of what spirituality is and the extent of it's boundaries. The sphere of spirituality plays a significant role also in situations with no way out, which is cancer [9].

Religion is associated with spirituality, with the difference that we look at religion as the confession of a cult strongly associated with some ideal to which we aspire. Religiosity rooted 
is in polish tradition. In contrast, spirituality is more individual. This refers to the fact that we are the creatures compound of of flesh and spirit, and as we take care of our body physically so we should work on our spirit to get a harmonious whole. The body without a soul is just cells that build tissues and tissues that make up the systems working together. When there are limitations of the body, for example due to illness, there are also restrictions related to the spirit, e.g. with uncertainty, anxiety and fear. Religious practices often are helpful getting rid of these constraints that have proven their effects in many studies. The effects of these practices vary from the mood, increasing tolerance to pain, until even greater resistance to depression [10].

Pain and suffering in religious practice are reflected as something what could help us to get to holiness, achieving the expected path after death. Sick people are often looking for answers for the meaning of suffering and their struggle with the disease. Often the question is asked "why do I?". Spirituality related to faith and religious practice helps patients understand the situation at general by reference suffering, which they carry daily as part of their lives leading to saved. [11]

Those who fight against tumor clearly need closeness and spiritual support of loved ones, as well as support of medical staff. In Poland, if the patient needs, is able to obtain the spiritual help of which says the law on patients' rights and patient's rights ombudsman in the art. 36 " A patient staying in a therapeutic entity carrying out medical activities in the stationary type, has benefits for health under the provisions on medical activity has the right to pastoral care." As well as in case of deterioration of health or threat to life medicinal entity "is obliged to allow the patient to contact the priest of his religion" (art. 37). Therapeutic entity bears the costs of implementing these patients' rights (Art. 38).

Spirituality in the treatment of cancer often meets with problems from the ethical. They result from the decision on the form of treatment and the right moment to stop or abandon overzealous therapy. All medical procedures performed for the terminally ill patients. Those procedures are designed to maintain vital functions if ethics terms are good - if not we extend the time of the dying patient. Spirituality in the treatment of cancer often meets with problems from the ethical. They result from the decision on the form of treatment and the right moment to stop or abandon overzealous therapy. All medical procedures performed in the terminally ill, which are designed to maintain vital functions in terms of ethics are good, if not we extend the power of the dying patient. It is very difficult, because hard to determine the border, we can only suggest the general state of the patient, the results of research and based on the opinion of the treating physician. We meet in then with the moral problem of the attitude of the family, which as you know will always want to keep a patient alive and find confidence in the fact that the patient will be better than his departure forced detention alive. In this period we must remember, that in spite of the resignation by the end of activities to provide the necessary care and spiritual oblivious to what is most important or the dignity of the patient [12]. Treatment of a patient with cancer is not always radical character, seeks to cure. If this is so, the religious man finds hope to achieve a positive treatment effect. The patient puts in God, the holy patrons hope for a cure and life after cure. However, when the cancer is detected too late, or the treatments used did not bring results, then the only thing that medicine can offer treatment to the patient is terminal. The essence of palliative treatment is to maintain the highest possible quality of life for the patient, this objective is a priority on extending the life of the patient. In the case of palliative treatment religiosity patient to another dimension. The patient is often aware that approaching the end of his life on earth. Depending on the religion it is time to summarize your life, think about what was good in him and what is bad. It is also a time in which many would like to settle your life matters, including reconciliation with other people, meet for the last time. At the end of life, the 
question arises on which the answer is in the patient's faith, regarding his fate after death. Different religions in different ways treat and describe life after death. For many, one common denominator is the reward for a good life and temporal punishment for not living up to the code of faith. Especially those who during their life more burdened conscience evil deeds may have a bigger problem with the acceptance of inevitable death and perhaps bear the consequences of their behavior.

\section{The perception of death and suffering by the major religions}

All 5 of religion presented below have at least a few fragments therefore necessary to simplify were applied.

\section{Christianity}

The whole teaching of religion and the cult refers to the creation of the man in the image and likeness of God and the redemption of sins through Christ's passion and death which liberated the world from evil and appointed a man to immortality. According to the tenets of the Christian religion, at the time of death the soul leaves the body, and then it stand before the court of God where man is accountable for the deeds of earthly life. The soul may go to heaven or hell or purgatory. It is respectively the path of eternal paradise, condemnation or the path to paradise to atone for evil deeds. In addition, Christianity puts a strong emphasis on the acceptance of suffering at the same time calling for the active prevention by helping. Health is a fundamental value because it enables a self-realisation, however it is not the most important value. This religion emphasizes the value and dignity of the sick person, and even sees the disease as an opportunity to purify and obtain the merits necessary for salvation. That is why the Christian in his suffering can find meaning and identify with Christ himself, who through his suffering made redemption. A very important role in the religious life of Christians was played by miraculous healings, which were considered a grace (reward) from God and strengthened faith. Christianity gives relief to suffering and the hope of a better life after death, as a compensation for suffering found on Earth [13].

\section{Judaism}

In Judaism man is perceived as unity. Body and soul are inseparable, because of this, there is a duty to care for their health. Jews believe in an immortal soul, but after death the soul cannot be improved, this is only possible by means of the body. Religious duties are i.a. wash hands after getting up, before a meal, or after using the bathroom. They believe that what happens after death is definitely different from human life so far but they emphasize that no one knows what their paradise will look like. They assume that it will be something very, very good because it comes from God. Thus, the followers of Judaism thanks to their religion find support in staying a long way of healing. Thus the Jews by their religion are finding support in traversing a long road of treatment. The need to care for the body supports the healing process and contributes, for example, thanks to increased hygiene to strengthen health. Jews as the followers of the immortal soul, their hope for further life after death. This allows them to gently pass through illness and death, knowing that life does not end, but will continue on, but in a different, better reality [13].

\section{Islam}

Islam is a religion where the health condition of the body and the soul depend on faith in God and uncompromising submission to his will. A lot of the provisions in Islamic law apply to health, such as the obligation to fast or regular prayer. Suffering for religious Muslim is part of the divine plan. Omnipotence of God in the Qur'an is not unappreciated. God gives, but also takes away, to whom He wants and when He wants, for the favors granted and the lack of 
them are a test to which man is exposed. The bitter taste of life is considered one of the elements of this life. Suffering is seen as one of the possibilities release your inner potential to move forward in your spiritual journey to become what it is "fruit of the tree of creation." The concept of suffering in the literature of Islam is not presented as a problem but as part of the human experience. Most of the Quranic verses deal with hardship and adversity, suggest that people, including prophets, will be tested in hard times. According to the Qur'an on the mystical path the sick man practice trust in God, patience and other virtues, which uncursed man is not able to see. Therefore, cancer, pain associated with it, or death according to Muslims is the divine plan, which should be subordinate. The awareness that suffering was sent from God makes it easier to go through the process of illness and dying. According to Muslims, on the Last Day all beings who lived on earth will be resurrected. It also makes you aware that life does not end, but will continue after death [14].

\section{Hinduism}

In this religion, first of all, human life is not dependent on death. Hindus believe in reincarnation. Each successive incarnation is continuation of life. That is why death is not considered as the end. Hindu traditions provide us with information that illness and disability is a result of improper actions in the past life. Moreover, suffering is regarded as an integral part of the cycle of life and rebirth. The inclusion of own suffering is an important part of the life cycle facilitating acceptance of own health situation.

They also believe that accepting suffering is the correct consequence of acts according to the laws of karma. This creates the danger that representatives of the Hindu religion will blame themselves for falling ill (not only as a consequence of anti-health behavior), but also in connection with acts that did not affect the disease. In addition, Hindu philosophy indicates that suffering is not only a negatively marked condition, but it can bring God closer [15].

\section{Buddhism}

The very first sermon of the Buddha was devoted to the suffering, pain and hardships of life. Buddhists in their practice tend to imagine the world as a "boundless sea of suffering." The main reflection Buddhist preachers is to end suffering and gain happiness. However, the word suffering "dukkha" refers rather to the specific causes of suffering. It is related to the suffering caused by external reasons such as war, famine, disease. Buddhism suggests that if life is not painful, it can be unsatisfactory and disappointing. According to the followers of the Buddhist religion, the soul is not immortal. After the death of a human being, man can enter another living being and shape himself, where the goal is to achieve the state of Nirvana. For a man professing religion Buddhist suffering has its explanation and effects, which facilitates the way through the suffering and death [16].

In the current world, in the second decade of the 21st century, the laicization of societies, especially highly developed countries, is observed. Many people dissociate themselves from the culture and traditions in which their parents or grandparents were brought up, part of which was religion. More and more people in these societies reject the ideas of the religions cited earlier. This may include complete or partial rejection of religions and their truths, including the meaning of suffering and death. Non-believers are often deprived of hope for another life after death and do not find meaning in suffering. Because of the disease process itself, therapy can take place in a different way. Atheists do not put their faith in God, but in the scientific achievements and experience of the people they put themselves into during treatment. 


\section{Summary:}

Man's life is for some miracle and a great gift for the other twist of fate, the work of evolution. Since our worldview depends on how we perceive life, suffering, death. There is happiness, health in life, but also the suffering often associated with lack of health.

1.Majority of religions of the world see suffering as an important part of the way of life, which can provide a relief for those suffering from cancer.

2.Most of the major religions of the world present the vision of the immortal soul, which gives hope to the dying people, that life does not end, but it will last, but in a different form.

3.Atheism, as well as low levels of religiosity may increase the fear of death and impede acceptance of suffering.

4. Developing knowledge by medical staff about the religion should be their good practice, allowing them to better understand and support patients.

\section{Bibliography:}

1. Lauren Wilson \& PrachiBhatnager Nick Townsend Comparing trends in mortality from cardiovascular disease and cancer in the United Kingdom, 1983-2013: JoinPoint regression analysis. Population Health Metrics no. 23 (2017) doi: 10.1186 / s12963-017-0141-5.

2. Dyzmann-Sroka, A., \& Malicki, J. (2014). Cancer incidence and mortality in the Greater Poland region-Analysis of the year 2010 and future trends. Reports of PracticalOncology \& Radiotherapy, 19 (5), 296-300. doi: 10.1016 / j.rpor.2014.04.001.

3. Demography and Social Gerontology - Information Bulletin 2013 No. 1 Institute of Sociology University of Lodz .

4. Malvezzi, M., Carioli, G., Bertuccio, P., Boffetta, P., Levi, F., La Vecchia, C., \& Negri E. (2019). European cancer mortality predictions for the year 2019 with focus on breast cancer. Annals of Oncology. doi: 10.1093 / annonce / mdz051.

5. https://www.wcrf.org/dietandcancer/cancer-trends/worldwide-cancer-data 11/26/2019.

6.https: //www.wcrf.org/dietandcancer/cancer-trends/worldwide-cancer-data? 28.11.2019.

7. Vinay Kumar, RamziCotran; Robbins Patologiawyd. Wroclaw 92014 pp. 173-174, 177181.

8. Brodowicz-King, M., Zarzycka D Stadnicka S., E. Bartoń holistic professional skills nursing students Master. Journal of Education, Health and Sport, 2016, No. 8, pp. 113-124.

9. Catherine Skrzypińska boundaries of spirituality. Annals of psychology, Lublin 2012, Volume 15 s.75-95.

10. Marius Swart, healthcare ethics for for healthcare practitioners, African sun MEDIA 2017, pp. 114-128.

11. M. Klimasiński, Ziemkiewicz M. Neumann-Klimasińska N. spiritual needs of patients important in everyday clinical practice. Palliative Medicine 2017: 9 (4): pp. 210-217.

12. Rauch $\mathrm{G}$. The problem of death in the legal and ethical perspective. Legal online overview. UJ TBS-P 2 (46), 2019 Krakow.

13. Jakub Pawlikowski, Krzysztof Marczewski Religion and Health - whether religion can promote health concerns? Vol. 1 The value of health in the great religions of the world. Cardiology after graduation in 2008 Volume 7 no. 10.

14. J. Pruszyński Jacek, Jacek Putz, Dorothy Cianciara religious and cultural conditions needs Muslims during health and disease, Hygeia Public Health 2013, 48 (1): 108-114.

15. Sarah M. Whitman, Pain and Suffering as Viewed by the Hindu Religion of The Journal of Pain 2007, Vol 8, No 8 percentage points. 607-613.

16. Paul Wong and Lilian Wong Handbook of Multicultural Perspectives on Stress and Coping ed.New York Springer 2006 Chapter 4, pp.73-89. 